\title{
Education of Prevention and Treatment in Diabetes Mellitus Feet
}

\author{
Rusdiana $^{1 *}$, Maya Savira ${ }^{2}$, Sry Suryani Widjaja ${ }^{1}$ \\ ${ }^{I}$ Departemen Biokimia, Fakultas Kedokteran Universitas Sumatera Utara \\ ${ }^{2}$ Departemen Fisiologi, Fakultas Kedokteran Universitas Sumatera Utara
}

\begin{abstract}
Diabetes Mellitus is also known as "life long disease" because the disease cannot be cured during the life span of the sufferer so that people with diabetes have a risk of complications that can increase the risk of death. Diabetic foot injury is one of the most common complications, where this complication can result in decreased quality of life. With a good level of understanding of diabetes mellitus and the complications that occur we hope to reduce the incidence of diabetes foot injuries in people with diabetes mellitus. As a community team, we conduct community services which the support is under the research grant BP-PTN USU of Year 2019PPM/KP-TALENTA USU/2019, giving education on prevention and treatment of diabetic foot ulcer in Medan Johor Public Health Centre in Sumatera Utara. In this activity the cross-sectional study was used with 40 respondents in type 2 diabetes mellitus who attended to public health centre and We educated them. The education provided included how to prevent and treatment of the foot ulcer of diabetes mellitus. The care and prevention of the education we provided includes how to properly take care of the feet, the periodic of glycemic control, the balanced diet and doing diabetes gymnastics. All the respondents who got the education, 25 from 40 respondents knew and did the foot care and who knew about the foot gymnastics were only 2 respondents.
\end{abstract}

Keywords: Diabetes mellitus, Foot ulcer of the diabetes, Education

\begin{abstract}
Abstrak. Diabetes Mellitus juga dikenal sebagai "penyakit seumur hidup" karena penyakit ini tidak dapat disembuhkan selama masa hidup penderita sehingga penderita diabetes memiliki risiko komplikasi yang dapat meningkatkan risiko kematian. Cedera kaki diabetik adalah salah satu komplikasi yang paling umum, di mana komplikasi ini dapat mengakibatkan penurunan kualitas hidup. Dengan tingkat pemahaman yang baik tentang diabetes mellitus dan komplikasi yang terjadi, kami
\end{abstract}

*Corresponding author at: Departemen Biokimia, Fakultas Kedokteran Universitas Sumatera Utara, Medan, Indonesia

E-mail address: drrusdiana@gmail.com 
berharap dapat mengurangi insiden cedera kaki diabetes pada orang dengan diabetes mellitus. Sebagai tim komunitas, kami melakukan layanan komunitas yang dukungannya berada di bawah hibah penelitian BP-PTN USU Tahun 2019PPM / KP-TALENTAUSU/2019, memberikan pendidikan tentang pencegahan dan pengobatan ulkus kaki diabetik di Pusat Kesehatan Masyarakat Medan Johor di Sumatera Utara Pada kegiatan ini dilakukan studi cross sectional dengan 40 responden pada diabetes melitus tipe 2 yang menghadiri ke pusat kesehatan masyarakat dan Kami mendidik mereka. Pendidikan yang diberikan termasuk bagaimana mencegah dan pengobatan tukak kaki diabetes mellitus. Perawatan dan pencegahan pendidikan yang kami sediakan meliputi cara merawat kaki dengan benar, kontrol glikemik berkala, diet seimbang dan melakukan senam diabetes. Semua responden yang mendapatkan pendidikan, 25 dari 40 responden tahu dan melakukan perawatan kaki dan yang tahu tentang senam kaki hanya 2 responden.

Kata Kunci: Diabetes mellitus, Ulkus kaki diabetes, Edukasi

Received 10 January 2020 | Revised 20 February 2020 | Accepted 25 March 2020

\section{Introduction}

Diabetes mellitus was a chronic disease that occurs when the pancreas does not produce enough the insulin or when the body cannot effectively used the insulin produced [1]. In the 2015 International Diabetes Federation, 415 million people had diabetes mellitus. This number is expected to increase to 642 million by 2040. The increasing prevalence of people with diabetes mellitus will certainly increase the number of complications at both the cellular and anatomic levels.

Diabetics are very at risk of foot injury, generally chronic and difficult to cure. Nerve damage occurs in $60-70 \%$ of diabetic population [2]. Diabetic foot ulcer is the most dreaded complication of diabetes mellitus [3] and around $15 \%$ of diabetic patients will experience at least one leg ulcer during their lifetime and often lead to amputation of the toe, foot or leg [4]. Diabetics in Indonesia rank seventh after China, India, America, Brazil, Russia and Mexico. The population of diabetics in Indonesia in 2015 amounted to 10 million people [5] .

Because of diabetic foot complications become a complicated problem because not many interested people are motivated to pursue diabetes foot care, education is still limited specifically for managing diabetic feet. Knowledge about community diabetes feet, especially diabetes, is felt to be still low and the high cost of managing diabetes feet [6]. 


\section{Methods}

We recruited the samples from Medan Johor Primary Health Care (PHC), North Sumatera, Indonesia. This was conducted from April to September 2019 and this study is a cross-sectional descriptive, which aims to determine the frequency of respondents who knew and perform foot care and foot gymnastics, using cross sectional research. This study was conducted at Medan Johor Health Center and was approved by our Institutional Health Research Ethics Committee under number 484/TGL/KEPKFK USU-RSUP HAM 2019. The respondents were diabetes mellitus type 2 who attended to Medan Johor Health Center, as many as 40 respondents. We collected the data in this study using the two of questionnaires, namely questionnaire A respondent characteristics made by the researcher consists of (gender, age, education, and duration of diabetes). Questionnaire B (knowledge of diabetic foot answers).

This research was conducted in relation with community service activities carried out by the Community Service team consisting of the lecturers at the Medical Faculty, Universitas Sumatera Utara and the students of the Medical Faculty to sufferers of the type 2 diabetes mellitus at Medan Johor health center. We collected 40 people who suffered from the type 2 diabetes mellitus who were routine patients seeking treatment at Medan Johor health center. We carried out this activity from April - September 2019. The education that we provided was in the form of prevention and treatment of the foot ulcer in diabetic where we conducted the educational method with lectures and discussions. Before education we took measurements of the respondents including the body weight, height, waist circumference and the blood pressure measurements. We also examined the blood sugar levels by using the fortable mechine. We provide a questioner to find out the knowledge of the respondents about the foot care and gymnastics feet. In addition, we also provide the leaflets in the form of coverage on how to properly care for the feet and the movements contained in the gymastics feet.

The data collection was carried out when the respondent attended to the Public Health Center. This activity began with a work contract with the Chief of the public Health Center and the medical staff working on the Prolanis program. Furthermore, directly related to the respondent, explain the purpose, purpose of this activity, explain the rights of the respondent. After agreeing, the respondent is given approximately 10-15 minutes to complete the questionnaire that has been prepared. 
There are several scopes covered in the provision of education that we provide in this community service program, which we describe in the table below.

Table 1. The content of education programme for the patients

The education about diabetes mellitus

- Understanding of the diabetes mellitus.

- Introduction of diabetes mellitus symptoms.

- Examination that must be done routinely.

- If the respondents has been diagnosed by the diabetes mellitus and cannot be treated with the diet and exercise only so used of the drug routinely.

Education about the dangers of diabetes mellitus complications in the form of the feet ulcer

- Feet ulcer: complications of the diabetes mellitus patients that often occur in patients that was not controlled of the blood sugar levels.

- A thorough understanding of the causes of diabetes mellitus.

- Education to be able to change the lifestyle of diabetics.

Education about the foot care

- Proper foot hygiene care: Clean the feet every day with the clean water and the soap.

- Give the moisturizer (lotion) on the dry leg area so that the skin does not become cracked, but not between the toes because it will be moist and can cause mold.

- Straight toe nail clippers follow the normal shape of the toes not too close to the skin then nail file with so as not sharp.

- $\quad$ Use correct and appropriate footwear to avoid injury.

Teaches the gymnastic foot

At this stage we do education in the form of how to do the gymnastic feet for the respondents, how long should to do the exercise every day, also do the gymnastic demonstration performed for the respondents.

The examination of Glycemic control: The educating respondents to routinely carry out glycemic control to avoid complications of diabetes mellitus.

\section{Results and Discussions}

Respondents who did foot care were 25 people while those who did not do foot care were 15 people, participants who did sports were 10 people while those who did not do sports were 30 people. But the participants who knew about foot gymnastics in diabetes 
mellitus from 40 participants were only two people who knew about diabetes gymnastics which is one of the ways in preventing injuries in diabetic feet (Table 1).

Table 1. The characteristics of the responden in Medan Johor of the Public Health Centre $(n=40)$

\begin{tabular}{lccc}
\hline \multirow{2}{*}{ Gender } & & Frequency & Percentage $(\%)$ \\
& Male & 10 & 25 \\
Age group & Female & 30 & 75 \\
& $<55$ years old & 11 & 27.5 \\
\multirow{2}{*}{ Education level } & $>55$ years old & 29 & 72.5 \\
& Junior high school & 10 & 25 \\
Duration of & Senior high school & 23 & 57.5 \\
Diabetes & Academy/university & 7 & 17.5 \\
Doing foot care & $<5$ years & 18 & 45 \\
& $>5 y e a r s$ & 22 & 55 \\
Activity & Yes & 25 & 62.5 \\
Knowing the & No & 15 & 37.5 \\
foot gymnastic & Yes & 10 & 25 \\
\hline
\end{tabular}

The education that we provide about the prevention of the foot ulcer of diabetic in which the coverage contained in this education is in the form of knowledge about how to care the foot in order prevented the ulcer. To find out the frequency of the respondents who know and do foot care, we collect education level data from respondents so we get data that at the junior high school education level of 10 respondents who did foot care, the senior high school education level of 23 respondents found 8 respondents who know and do foot care, while at the academy level there are 4 respondents out of 7 who know and do foot care (Table 2).

Table 2. The knowledge of the foot care in Medan Johor Health Center based on the level of education

\begin{tabular}{lcrrrrr}
\hline & \multicolumn{7}{c}{ The foot care } & \multicolumn{2}{c}{ Yes } \\
& $\mathrm{f}$ & $\%$ & $\mathrm{f}$ & $\%$ & $\mathrm{f}$ & $\%$ \\
Junior high school & 7 & 70 & 3 & 30 & 10 & 100 \\
Senior high school & 8 & 34.8 & 15 & 65.2 & 23 & 100 \\
Academy/university & 0 & 0 & 7 & 100 & 7 & 100 \\
\hline
\end{tabular}


The education about the gymnastics diabetes for facilitating the blood flow in circulation in the lower extremities. The gymnastics can be done anywhere. As for the respondents who know about the gymnastics diabetes from 40 respondents, 3 respondents who knew and do the gymnastics, 2 people at the academy education level and 1 person at the senior high school education level (Table 3).

Table 3. The knowledge of the foot gymnastics of diabetes mellitus based on the education level

\begin{tabular}{lccccccc}
\hline & \multicolumn{5}{c}{ The Gymnastic foot } \\
\multirow{2}{*}{ Level Education } & \multicolumn{1}{c}{ Total } & Not & \multicolumn{2}{c}{ Yes } \\
\cline { 2 - 8 } & $\mathrm{f}$ & $\%$ & $\mathrm{f}$ & $\%$ & $\mathrm{f}$ & $\%$ \\
\hline Junior high school & 10 & 100 & 0 & 0 & 10 & 100 \\
Senior high school & 22 & 95.7 & 1 & 4.3 & 23 & 100 \\
Academy/university & 5 & 71.4 & 2 & 28.6 & 7 & 100 \\
\hline
\end{tabular}

The results of this study found that there were more female respondents than male. According to the opinion of Lueckenotte cit Sofiana [7] female are more affected by diabetes than male, especially type 2 diabetes mellittus. This is caused by decreased production of the hormone estrogen which maintains the homeostasis of the blood sugar levels and increases fat storage. Respondents who participated in this study with more than 55 years old were more than those under 55 years old. Diabetes mellitus often occur after the age 40 years old [8]. By increasing the age glucose tolerance will occur. The aging process also causes physiological changes to affect homeostasis. One of them is a change in the pancreatic beta cell function. The degenerative process of the beta cells will cause inadequate in the producing insulin and have an impact on increasing blood sugar levels. According to the results of Sundari's study [9] changes due to age such as vascular changes are related to the occurrence of peripheral insulin resistance in type 2 diabetes mellitus. Decreased glucose intolerance influenced peripheral cell sensitivity to insulin. This is what causes an increasing in blood sugar levels in the old age.

In this study 40 respondents participated in which the level of junior high school education was 23 people. A good level of knowledge is needed in receiving the education about the treatment and prevention of the foot ulcer in diabetic, as according to Notoatmodjo [10] where his concept states that the higher the education the easier it was to receive, process information. It is expected that the education we provide can 
improve respondents' understanding of diabetes and its complications where, with the understanding of the care and the prevention, correctly and goodly so the complications of the ulcer foot in diabetes mellitus can be avoided [10].

The duration of diabetes mellitus for the respondents in this study were more than 5 years more than less than 5 years, as we know that diabetics in the study also suffered more by age $>55$ years. The risk of developing the foot ulcer of diabetes mellitus increased by age and duration of illness [11]. In addition, male diabetics have a higher risk of developing the foot ulcer compared to diabetic female [12]. In this study all the respondents who participated did not have complaints of the foot ulcer of diabetes mellitus and all the respondents knew that they had diabetes mellitus based on the results of the examining blood sugar levels. With this education that we provide, we urged the respondents to routinely examined for their blood sugar levels both independently or visited to the public health centre in the area where they live, the Medan Johor Public Health Centre.

The respondents in this study who did the foot care of 25 people from 40 respondents where the level of knowledge about the foot care at the level of senior high school education and the academy frequency is more frequent than the junior high school education level. Knowledge level and the foot care taken by respondents are one way to prevent the occurrence of the ulcer foot of diabetes mellitus. According to Soegondo [13] every patient needed to know the diabetic foot care goodly to prevent gangrene ulcers and amputations [14]. The foot care for diabetics was very important because the feet are organs that were vulnerable to ulcer. In addition, the foot as a buffer of the body has many nerves that are connected with other body organs [15]. Foot gymnastics also can strengthen the small muscles of the foot and prevent foot deformities [16]. The strength of the calf muscles, thigh muscles, and also overcomes the limitations of motion can also be overcame [17]. The activity of education for the type 2 diabetes mellitus patients in this Primary Health Care in Medan Johor were usefull for increasing understanding that by the control glycemic index, doing foot care and footgymnastic preventing foot ulcer for complication type 2 diabetes mellitus patients.

\section{Conclusions}

The conclusion of this community service activities is that improving that the health education in Medan Johor PHC, North Sumatera, increasing awareness for diabetes mellitus patients about preventive of food ulcer such as jogging or aerobic for $30 \mathrm{~min}$ every day or awareness of activity daily does not consider exercise but this activity 
has several limitations: A short period of health education and the subjects in the study were also more elder, so our education was less valuable if the subjects more younger than our subjects maybe the results more valuable

\section{Acknowledgments}

The authors gratefully acknowledge that the present research is supported by Ministry of Research and Technology and Higher Education Republic of Indonesia. The support is under the research grant BP-PTN USU of Year 2019 Contract Number: 176/UN5.2.3.2.1/PPM 2019.

\section{References}

[1] Word Health Organitation. Fact Sheet Diabetes. 2015. (Access at http://www.who.int/mediacentre.)

[2] M. Winnie, Edward, Edodge, C. M. Auxilia, and M. George, "Nonadherence to treatment among diabetic patients attending outpatients clinic at Mutare provincial hospital". Manicaland province, Zimbabwe, vol. 3, pp. 66-86, 2014.

[3] C. Subhash, "Diabetic Foot Ulcer - A Case Study". Journal of Exercise Science and Physiotherapy, vol. 1, 98-99, 2005.

[4] A. Maryunani, Step By Step Perawatan Luka Diabetes dengan Metode Perawatan Luka Modern. Jakarta: In Media. 2013.

[5] D. Cavan, Internasional Diabetes Federation Seventh Edition. 2015. (Access at www.diabetesatlas.org).

[6] Ernawati, Penatalaksanaan Keperawatan Diabetes Melitus Terpadu. Jakarta: Mitra Wacana Media. 2013.

[7] L. I. Sofiana, V. Elita, and W. Utomo, "Hubungan Antara Stress dengan Konsep Diri pada Penderita Diabetes Melitus Tipe 2". Jurnal Ners Indonesia, vol. 2, no. 2, pp. 167-176, 2012.

[8] S. C. Smeltzer, B. G. Bare, J. L. Hinkle, and K. K. Cheever, "Brunner \& Suddarth's: Textbook of Medical-Surgical Nursing (12 ${ }^{\text {th }}$ ed)". Philadelphia: Lippincott Williams \& Wilkins. 2010.

[9] A. Sundari, K. Aulawi, and D. Harjanto, "Gambaran Tingkat Pengetahuan Tentang Ulkus Diabetik dan Perawatan Kaki pada pasien Diabetes Melitus Tipe 2”. JIK, vol. 4, no. 3, pp. 181-190, 2009.

[10] S. Notoatmodjo, Promosi Kesehatan dan Perilaku Kesehatan. Jakarta: Rineka Cipta. 2012.

[11] N. Singh, D. G. Armstrong, and B. A. Lipsky, "Preventing foot ulcers in patients with diabetes". JAMA, vol. 293, pp. 217-228, 2005.

[12] C. A. Abbott, "The North West Diabetes Foot Care Study: Incidence of and risk factors for new diabetic foot ulceration in a communitybased cohort". Diabetic Medical, vol. 19, pp. 377-384, 2002.

[13] Soegondo and Sidartawan. Penatalaksanaan Diabetes Mellitus Terpadu. Jakarta: FKUI. 2009. 
[14] D. Mozaffarian, T. Hao, E. B. Rimm, W. C. Willett, and F. B. Hu, "Changes in diet and lifestyle and long-term weight gain in women and men". New England Journal Medical, vol. 364, no. 25, pp. 2392-2404, 2011.

[15] G. Seghieri, L. Policardo, R. Anichini, F. Franconi, I. Campesi, and S. Cherchi, "The effect of sex and gender on diabetic complications". Current Diabetes Rev., vol. 13, no. 2, pp. 148-160, 2017.

[16] I. S. Muller, "Foot ulceration and lower limb amputation in type 2 diabetic patients in Dutch primary health care". Diabetes Care, vol. 25, pp. 570-574, 2002.

[17] A. Tyo, Senam Kaki Diabetes. http://akhtyo.blogspot.com/2008/04/senam-kaki-diabetes.html. 2009. (Accessed on 23 August 2009). 